\title{
PENGARUH PENGGUNAAN ELECTRONIC COMPONENT TESTER SEBAGAI MEDIA PEMBELAJARAN TERHADAP HASIL BELAJAR SISWA PROGRAM KEAHLIAN TEKNIK AUDIO VIDEO SMKN 1 SUMBAR
}

\author{
Delsina Faiza ${ }^{1}$ \\ Thamrin ${ }^{2}$ \\ Ahmaddul Hadi ${ }^{3}$
}

\begin{abstract}
This study aims to determine the effect of the use of Electronic Component Tester as instructional media to the students' learning outcomes in Audio Video Techniques Program SMK N 1 Sumbar on basic competence classify passive and active components in electrical and electronic circuit. The research method used in this research, especially in the design of Electronic Component Tester is Research and Development $(R \& D)$ research, which consists of media design, validation, revision, product manufacture, and testing. After the learning media is validated, experimental research will be conducted where the Electronic Component Tester will be used as a learning medium for the students of Audio Video Technique SMKN 1 Sumbar in basic competence to classify passive and active components in electrical and electronic circuits. Prior to treatment, students were given a pre-test to determine initial ability. After being given the use of Electronic Component Tester as a learning medium, a post-test was done to determine the group's ability improvement. Pre-test results obtained an average value of 50.60, while the post-test results obtained an average value of 61.90. Learning outcomes after applied Electronic Component Tester learning media was Increased by 11.31 point. Result of calculation at significant level $\alpha=$ 0,05 got $t_{\text {count }}>t_{\text {table }}$ that is 2,905> 2,056. It can be concluded there is improvement of student learning outcome after using instructional media Electronic Component Tester in basic competence classify passive and active component in circuit electrical and electronics students Audio Video Technique Program in SMK N 1 Sumbar.
\end{abstract}

Keywords: Electronic Component Tester, Learning Media, Learning Outcomes.

\section{INTISARI}

Penelitian ini bertujuan untuk mengetahui pengaruh penggunaan media pembelajaran berupa Electronic Component Tester terhadap hasil belajar siswa program keahlian Teknik Audio Video SMK N 1 Sumbar pada kompetensi dasar mengklasifikasikan komponen pasif dan aktif pada rangkaian listrik dan elektronika. Metode penelitian yang digunakan dalam penelitian ini, khususnya

\footnotetext{
${ }^{1}$ Fakultas Teknik Universitas Negeri Padang

${ }^{2}$ Fakultas Teknik Universitas Negeri Padang

${ }^{3}$ Fakultas Teknik Universitas Negeri Padang
} 
dalam perancangan Electronic Component Tester adalah penelitian Research and Development (R\&D), yang terdiri dari perancangan desain, validasi desain, revisi desain, pembuatan produk, dan ujicoba. Setelah media pembelajaran selesai dibuat akan dilakukan penelitian eksperimen dimana Electronic Component Tester akan digunakan sebagai media pembelajaran pada siswa program keahlian Teknik Audio Video SMKN 1 Sumbar pada kompetensi dasar mengklasifikasikan komponen pasif dan aktif pada rangkaian listrik dan elektronika. Sebelum diberi perlakuan, siswa diberi pre-test untuk mengetahui kemampuan awal. Setelah diberikan perlakuan penggunaan Electronic Component Tester sebagai media pembelajaran, dilakukan post-test untuk mengetahui peningkatan kemampuan kelompok. Dari hasil pre-test didapatkan nilai rata-rata 50,60, sedangkan hasil post-test mendapatkan nilai rata-rata 61,90. Peningkatan hasil belajar setelah diterapkan media pembelajaran Electronic Component Tester sebesar 11,31. Hasil perhitungan pada taraf signifikan $\alpha=0,05$ didapatkan $t_{\text {hitung }}>t_{\text {tabel }}$ yaitu $2,905>2,056$, karena $t_{\text {hitung }}$ besar dari $t_{\text {tabel }}$, maka dapat disimpulkan terdapat peningkatan hasil belajar siswa setelah menggunakan media pembelajaran Electronic Component Tester dalam kompetensi dasar mengklasifikasikan komponen pasif dan aktif pada rangkaian listrik dan elektronika siswa program keahlian Teknik Audio Video di SMK N 1 Sumatera Barat.

Kata Kunci : Electronic Component Tester, Media Pembelajaran, Hasil Belajar

\section{PENDAHULUAN}

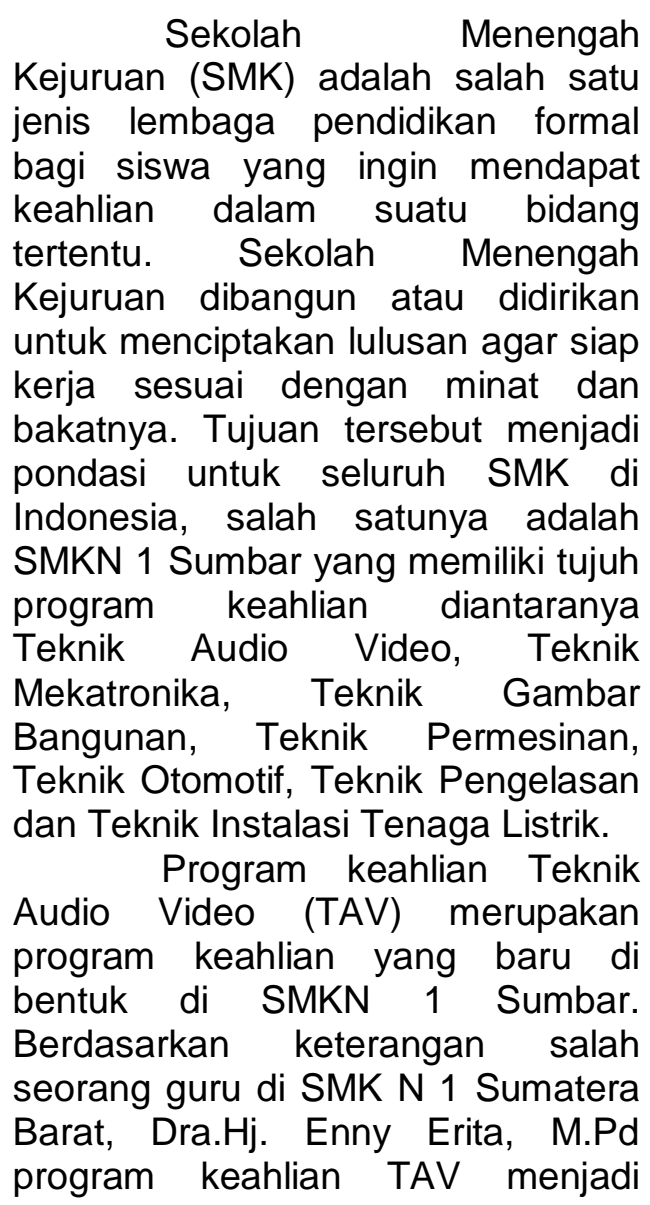

program keahlian favorit di SMKN 1 Sumbar karena jumlah siswa yang mendaftar melebihi kuota yang ditentukan.

Media pembelajaran yang digunakan oleh guru di program keahlian TAV adalah power point. Padahal mata pelajaran pada program keahlian TAV banyak sekali materi yang bersifat abstrak yang sebenarnya tidak bisa dijelaskan hanya dengan sebuah tulisan tetapi harus ditunjang dengan media lainnya yang dapat menggambarkan kondisi sebenarnya.

Salah satu solusi yang peneliti usulkan untuk mengatasi masalah ini adalah dengan Electronic Component Tester. Media dibuat dalam bentuk mini, sehingga lebih efektif dalam menjelaskan konsep komponen elektronika dalam pembelajaran teori. Sehingga dimungkinkan dengan aplikasi yang nyata, media menjadi lebih menarik, dan dapat membuat daya ingat siswa lebih lama tentang pengetahuan masing-masing 
komponen elektronika. Pembelajaran juga difokuskan kepada siswa, dengan menerapkan konsep pembelajaran demonstrasi untuk meng-explore ide-ide siswa.

\section{PENDEKATAN MASALAH}

\section{Tujuan Penelitian}

Tujuan yang ingin dicapai dari penelitian ini adalah :

1. Menghasilkan media pembelajaran interaktif Electronic Component Tester sebagai media yang tepat untuk kompetensi dasar mengklasifikasi komponen pasif dan aktif pada rangkaian listrik dan elektronika pada program keahlian teknik audio video di SMK N 1 Sumbar.

2. Mengungkap seberapa besar pengaruh penggunaan Electronic Component Tester sebagai media pembelajaran terhadap hasil belajar kompetensi dasar mengklasifikasi komponen pasif dan aktif pada rangkaian listrik dan elektronika pada program keahlian teknik audio video di SMK N 1 Sumbar

\section{TINJAUAN PUSTAKA \\ Media Pembelajaran}

Kata "media" berasal dari bahasa latin medius dan merupakan bentuk jamak dari kata "medium". Secara harfiah kata tersebut mempunyai arti perantara atau pengantar, Arief S. Sadiman (2012:6). Asosiasi Teknologi dan Komunikasi Pendidikan (Association of Education and Communication Technology/AECT) di Amerika, membatasi media sebagai segala bentuk dan saluran yang digunakan orang untuk menyalurkan pesan/informasi. Menurut Hamidjojo dalam Azhar Arsyad, (2013:4) menjelaskan bahwa "media adalah sebagai semua bentuk perantara yang digunakan oleh manusia untuk menyampaikan atau menyebar ide, gagasan, atau pendapat sehingga ide, gagasan, atau pendapat yang dikemukakan itu sampai kepada penerima yang dituju".

Berdasarkan penuturan para ahli diatas disimpulkan bahwa media merupakan sebuah alat yang digunakan sebagai perantara untuk menyalurkan informasi agar memudahkan penerima untuk memahami makna yang terkandung dalam informasi yang di sampaikan sehingga terciptalah proses interaksi timbal balik yang kompatibel antara pemberi informasi dengan penerima.

1. Pengertian Media Pembelajaran Media pembelajaran mempunyai arti tersendiri dalam proses belajar mengajar (PBM). Gagne' dan Briggs dalam Azhar Arsyad, (2013:4) secara implisit menyatakan bahwa media pembelajaran meliputi alat yang secara fisik digunakan untuk menyampaikan isi materi pengajaran. Menurut Cecep dan Bambang (2011:9) mengemukakan bahwa media pembelajaran merupakan sarana untuk meningkatkan kegiatan proses belajar mengajar.

Berdasarkan pendapat di atas dapat disimpulkan bahwa media pembelajaran merupakan sebuah alat yang digunakan sebagai perantara menyalurkan informasi yang digunakan oleh guru pada pembelajaran untuk menciptakan interaksi agar dapat merangsang fikiran, perasaan, dan kemauan siswa sehingga siswa lebih mudah memahami informasi yang disampaikan oleh guru dalam proses belajar mengajar.

2. Fungsi Media Pembelajaran

Salah satu fungsi utama media pembelajaran adalah sebagai alat bantu mengajar yang turut mempengaruhi iklim, kondisi, dan lingkungan belajar yang diciptakan oleh guru (Azhar Arsyad, 2013:19). Menurut Kemp 
dan Dayton yang dikutip oleh Cecep dan Bambang (2011:23) media pembelajaran dapat memenuhi tiga fungsi utama apabila media itu digunakan untuk perorangan, kelompok, atau kelompok pendengar yang besar jumlahnya, yaitu memotivasi minat atau tindakan, menyajikan informasi dan memberi instruksi. Sementara itu menurut Daryanto (2010:5-6), secara umum media pembelajaran memiliki beberapa kegunaan, yaitu dapat memperjelas pesan agar tidak terlalu bersifat hafalan, dapat mengatasi keterbatasan ruang, waktu, tenaga dan daya indera, dapat menimbulkan gairah belajar siswa, memungkinkan siswa belajar mandiri sesuai dengan bakat dan kemampuan visual, auditori dan kinestetiknya, serta dapat memberikan persepsi yang sama.

Berdasarkan pendapat para ahli diatas dapat disimpulkan bahwa fungsi dari media pembelajaran dalam sebuah pendidikan adalah memberikan kemudahan guru dalam berinteraksi dengan siswa dalam menyampaikan informasi pada proses pembelajaran sehingga dapat meningkatkan motivasi dan memungkinkan siswa untuk melakukan pembelajaran secara mandiri.

3. Manfaat Media Pembelajaran Azhar Arsyad (2013:29-30) mengemukakan manfaat dari penggunaan media pembelajaran di dalam proses pembelajaran sebagai berikut :

a. Media pembelajaran dapat memperjelas penyajian pesan dan informasi sehingga dapat memperlancar dan meningkatkan proses dan hasil belajar.

b. Media pembelajaran dapat meningkatkan dan mengarahkan perhatian siswa sehingga dapat menimbulkan motivasi belajar, interaksi yang lebih langsung antara siswa dengan lingkungannya, dan kemungkinan siswa untuk belajar sendiri-sendiri sesuai dengan kemampuan dan minatnya.

c. Media pembelajaran dapat mengatasi keterbatasan indra, ruang, dan waktu.

d. Media pembelajaran dapat memberikan kesamaan dan pengalaman kepada siswa tentang peristiwa-peristiwa di lingkungan mereka, serta memungkinkan interaksi langsung dengan guru, masyarakat, dan lingkungannya misalnya melalui karyawisata, kunjungan-kunjungan ke museum atau kebun binatang.

Berdasarkan penuturan ahli diatas, media pembelajaran memiliki beberapa manfaat dalam memperjelas pesan dan informasi yang disampaikan dalam proses pembelajaran sehingga mengarahkan perhatian siswa dan menimbulkan interaksi antara guru dan siswa. Media pembelajaran juga dapat memberikan kesamaan pengalaman kepada siswa karena media memungkinkan siswa untuk belajar secara mandiri.

Electronic Component Tester merupakan media pembelajaran yang digunakan sebagai tester komponen elektronik yang dapat mengukur nilai dan kelayakan dari komponen elektronika. Alat ini dapat menguji hampir semua jenis komponen pasif dan aktif kecuali IC (Integrated Circuit). Hal tersebut disebabkan karena IC merupakan 
komponen elektronika yang dibentuk dari beberapa komponen elektronika dasar berukuran kecil yang terintegrasi dalam bentuk rangkaian dan dilapisi dengan bahan semikonduktor.

Electronic component tester memiliki LCD berukuran 16x2 yang berfungsi sebagai display data dari komponen tester. Pengguna akan mengetahui data dari komponen yang diukur sesuai yang ditampilkan pada LCD. Pada kompetensi dasar mengklasifikasi komponen pasif dan aktif pada rangkaian listrik dan elektronika siswa diharapkan mampu untuk mengetahui cara membaca kode pada komponen elektronika. Sebagai contohnya pembacaan kode resistor. Jika menggunakan media multitester output tampilan hanya dalam bentuk resistansi. Sehingga untuk mengukur komponen seperti kapasitor, siswa tidak bisa membuktikan nilainya karena tidak ada skala ukur farad pada multitester.

\section{Hasil Belajar}

Keberhasilan dari suatu kegiatan pembelajaran dapat dilihat dari hasil belajar. Hasil belajar merupakan dasar yang digunakan untuk melihat tingkat keberhasilan siswa menguasai suatu materi pelajaran dan keberhasilan guru mengajar. Gagne dan Briggs dalam Jamil Suprihatiningrum (2013:37) menyatakan hasil belajar adalah kemampuan-kemampuan yang dimiliki siswa sebagai akibat perbuatan belajar dan dapat diamati melalui penampilan siswa. Sedangkan menurut Agus Suprijono (2012:5) "hasil belajar adalah polapola perbuatan, nilai-nilai, pengertian-pengertian, sikap-sikap, apresiasi dan keterampilan". Hasil belajar diberikan dalam bentuk nilai, dan biasanya dipengaruhi oleh kemampuan siswa dan bagaimana aktivitas siswa di dalam belajar.
Horward dalam Nana (2011:22) membagi hasil belajar dalam tiga macam yaitu:

1. keterampilan dan kebiasaan.

2. pengetahuan dan pengertian.

3. sikap dan cita-cita.

Menurut Slameto (2010: 54), faktor-faktor yang mempengaruhi hasil belajar adalah :

1. Faktor Intern

Faktor intern adalah faktor yang ada dalam diri individu yang sedang belajar. Faktor ini dapat digolongkan menjadi 3 golongan:

a. Faktor Jasmaniah

Faktor jasmaniah ini meliputi kesehatan dan cacat tubuh.

b. Faktor Psikologis

Ada enam faktor yang tergolong faktor psikologis yang mempengaruhi belajar, yaitu : intelegensi, perhatian, minat, motif, kematangan, dan kesiapan.

c. Faktor Kelelahan Kelelahan akan mempengaruhi belajar, agar dapat belajar dengan baik haruslah menghindari jangan sampai terjadi kelelahan dalam belajar sehingga perlu diusahakan kondisi yang bebas dari kelelahan.

2. Faktor Ekstern

Faktor ekstern adalah faktor yang datang dari luar individu. Faktor ekstern yang dapat mempengaruhi hasil belajar dapat dikelompokan menjadi tiga yaitu:

a. Faktor Keluarga

Siswa yang belajar akan

menerima pengaruh dari keluarga berupa cara orang tua mendidik, relasi antara anggota keluarga, suasana rumah tangga dan keadaan ekonomi, pengertian orang tua dan latar belakang kebudayaan.

b. Faktor Sekolah

Faktor sekolah yang mempengaruhi hasil belajar 
ini mencakup metode mengajar, kurikulum, relasi guru dengan siswa, relasi siswa dengan siswa, disiplin sekolah, standar pembelajaran, keadaan gedung, dan tugas rumah.

c. Faktor masyarakat

Masyarakat merupakan faktor ekstern yang juga berpengaruh terhadap hasil belajar pengaruh itu terjadi karena keberadaannya dalam masyarakat. Kegiatan dalam masyarakat dapat menguntungkan terhadap perkembangan pribadinya.

Menurut Nana (2011:22) menyatakan "Hasil belajar adalah kemampuan yang dimiliki oleh siswa setelah menerima pengalaman belajarnya". Jadi hasil belajar yang diperoleh siswa merupakan suatu tingkat penguasaan siswa terhadap apa yang telah dipelajarinya. Nana (2011:56) menyatakan hasil belajar yang dicapai siswa melalui proses belajar mengajar yang optimal cenderung menunjukkan hasil yang berciri sebagai berikut:

1. Kepuasan dan kebanggaan yang dapat menumbuhkan motivasi belajar intrinsik pada siswa.

2. Hasil belajar yang dicapainya bermakna bagi dirinya

3. Hasil belajar diperoleh siswa secara menyeluruh (komprehensif), yakni mencakup ranah kognitif, pengetahuan, serta ranah psikomotoris, keterampilan, atau prilaku.

4. Kemampuan siswa untuk mengontrol atau menilai dan mengendalikan dirinya terutama dalam menilai hasil yang dicapainya maupun menilai dan mengendalikan proses dan usaha belajarnya.

Berkaitan dengan kemampuan yang diperoleh sebagai hasil belajar Nana Sudjana (2011:22-23) membagi belajar dalam tiga ranah yaitu:
1. Ranah kognitif, yang meliputi, pengetahuan, pemahaman, aplikasi, analisis, sistetis dan evaluasi.

2. Ranah afektif, mencakup penerimaan, partisipasi, penilaian atau penentuan sikap, organisasi dan pembentukan pola sikap.

3. Ranah psikomotor, terdiri dari gerakan refleks, keterampilan pada gerakan-gerakan dasar, kemampuan perseptual, kemampuan di bidang fisik, gerakan-gerakan skill, dan kemampuan berkenaan dengan komunikasi non-decursive

Sukses atau tidaknya proses pembelajaran dapat dilihat dari hasil evaluasi yang dilakukan. Suharsimi Arikunto (2012:1) mengatakan evaluasi "sebuah proses pengumpulan informasi tentang sesuatu, digunakan untuk menemukan alternatif yang tepat dalam mengambil sebuah keputusan". Evaluasi yang baik harus dapat menilai pencapaian siswa dalam setiap aspek tujuan pendidikan dan tujuan itu harus dikemukakan dengan jelas sehingga dapat diamati dan diukur. Selanjutnya dalam Dimyati (1999:200) mengatakan "Evaluasi hasil belajar merupakan proses untuk menentukan nilai belajar siswa melalui penilaian atau pengukuran yang tujuan utamanya untuk mengetahui tingkat keberhasilan yang dicapai oleh siswa setelah mengikuti kegiatan pembelajaran, dimana tingkat keberhasilan tersebut kemudian ditandai dengan skala nilai berupa huruf, kata ,angka atau simbol.

Menurut Sardiman (2001: 47) hasil pengajaran dikatakan betulbetul baik,apabila memiliki ciri-ciri :

1. Hasil itu tahan lama dan dapat digunakan dalam kehidupan oleh siswa. Dalam hal ini guru akan senantiasa menjadi pembimbing dan pelatih yang baik bagi para 
siswa yang akan menghadapi ujian. Kalau hasil pengajaran itu tidak tahan lama dan lekas menghilang, maka hasil pengajaran itu berarti tidak efektif.

2. Hasil itu merupakan pengetahuan asli atau autentik. Pengetahuan hasil proses belajar mengajar itu bagi siswa seolah-olah telah merupakan bagian kepribadian bagi diri setiap siswa, sehingga akan mempengaruhi pandangan dan caranya mendekati suatu permasalahan. Sebab pengetahuan itu dihayati dan penuh makna bagi dirinya.

Faktor dominan yang mempengaruhi hasil belajar siswa di sekolah adalah metode mengajar dan media yang digunakan oleh guru. Metode pembelajaran dan media yang digunakan dengan materi pelajaran dan kondisi siswa akan membuat siswa menjadi lebih termotivasi dalam belajar sehingga segala kemampuan yang dimiliki siswa dapat berkembang dan tersalurkan dengan baik.

Berdasarkan pendapat para ahli yang telah diuraikan dapat disimpulkan bahwa hasil belajar adalah tingkatan penguasaan yang dimiliki siswa yang dapat ditunjukkan dalam berbagai bentuk seperti perubahan pengetahuan, pemahaman, sikap dan tingkah laku, keterampilan kecakapan, kebiasaan serta aspek-aspek lain yang ada pada diri inidividu setelah melakukan proses belajar yang diukur dengan melakukan evaluasi berupa nilai pembelajaran pada akhir semester.

\section{Metodologi Penelitian}

Penelitian ini merupakan jenis penelitian eksperimen. Menurut sugiyono (2017:72) "metode eksperimen adalah metode penelitian yang digunakan utuk mencari pengaruh perlakuan tertentu terhadap yang lain dalam kondisi yang terkendalikan".

Langkah-langkah dalam

penelitian eksperimen pada dasarnya hampir sama dengan penelitian lainnya. Menurut Gay (2012 : 201) langkah-langkah dalam penelitian eksperimen yang perlu ditekankan adalah sebagai berikut.

1. Adanya permasalahan yang signifikan untuk diteliti.

Materi pelajaran pada program keahlian teknik audio video di SMK bersifat abstrak yang sebenarnya tidak bisa dijelaskan hanya dengan sebuah tulisan tetapi harus ditunjang dengan media lainnya yang dapat menggambarkan kondisi sebenarnya, serta belum adanya media pembelajaran yang tepat untuk menjelaskan kompetensi dasar mengklasifikasi komponen pasif dan aktif pada rangkaian listrik dan elektronika.

2. Tempat dan waktu penelitian Penelitian ini dilakukan di SMKN 1 Sumbar pada program keahlian Teknik Audio Video.

3. Pemilihan subjek yang cukup untuk kelompok eksperimen.

Populasi pada penelitian ini adalah seluruh siswa program keahlian Teknik Audio Video SMKN 1 Sumbar yang terdaftar pada semester 1 tahun pelajaran 2017/2018 terdiri dari 2 kelas yang berjumlah 28 siswa.

Karena jumlah siswa TAV SMKN 1 Sumbar berjumlah 28 siswa, maka penelitian ini merupakan penelitian populasi. Oleh karena itu sampel yang diambil sejumlah populasi yaitu 28 siswa.

4. Variabel penelitian

1) Variabel bebas

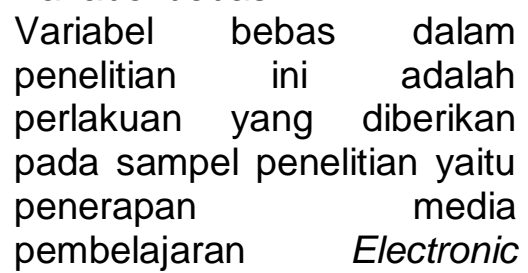




\author{
Component Tester pada \\ kelas eksperimen \\ 2) Variabel terikat \\ Variabel terikat dalam \\ penelitian ini adalah hasil \\ belajar siswa setelah \\ diberikan perlakuan.
}

5. Pembuatan atau pengembangan instrumen.

Metode yang digunakan dalam pengembangan instrument / media adalah pendekatan penelitian pengembangan atau Research and Development (R\&D) .

a. Tahap analisis

Kegiatan analisis dilakukan melalui kegiatan studi lapangan dan studi literatur. Studi lapangan dilakukan dengan cara observasi langsung ke sekolah. Tujuan dari observasi untuk menentukan kebutuhan media pembelajaran kompetensi dasar mengklasifikasi komponen pasif dan aktif pada rangkaian listrik dan elektronika.

Analisis berikutnya dengan kegiatan studi literatur. Studi literatur dengan cara melakukan kajian teori melalui buku-buku dan sumber informasi lainnya berkaitan dengan media pembelajaran yang akan dikembangkan.

b. Tahap Desain (Design)

Tahap desain merupakan langkah untuk merencanakan media pembelajaran yang akan dikembangkan sesuai permasalahan yang ditemukan saat tahap analisis.

c. Tahap Pengembangan (Development)

Tahap pengembangan ini meliputi :

1) Analisis kebutuhan
Pembuatan produk dilaksanakan setelah menganalisis kebutuhan dan pengumpulan komponen serta peralatan kerja. Analisis kebutuhan komponen dan alat kerja disesuaikan dengan hasil desain produk. Penggunaan komponen juga dipertimbangkan dengan menggunakan komponen yang mudah didapatkan. Hal tersebut dilakukan agar proses pengembangan berjalan lancar dan apabila ada kerusakan komponen mudah didapatkan kembali untuk perbaikan.

2) Pembuatan Electronic Component Tester

Pembuatan dan pengembangan

Electronic Component Tester terbagi menjadi beberapa tahap, yaitu: perancangan media, pembuatan media, dan pengujian media.

3) Ujicoba

Tahap ujicoba dilaksanakan untuk mendapatkan pernyataan kelayakan dari ahli media dan ahli materi. Ujicoba ini melibatkan ahli media dan guru untuk menilai produk sebelum diterapkan dalam pembelajaran. Hasil dari ujicoba dijadikan masukan untuk memperbaiki produk. Produk akan diterapkan dalam pembelajaran bila telah dinyatakan layak oleh para ahli.

6. Pemilihan desain penelitian Desain penelitian yang digunakan dalam penelitian ini adalah time series design. Dalam 
design ini, peneliti melakukan pengukuran pada satu kelompok baik sebelum maupun setelah diberi perlakuan.

Kelompok A :

$$
\mathrm{O}_{1}-\mathrm{O}_{2}-\mathrm{O}_{3}-\mathrm{O}_{4}-\mathrm{X}-\mathrm{O}_{5}-\mathrm{O}_{6}-\mathrm{O}_{7}-\mathrm{O}_{8}
$$

Pengaruh adanya perlakuan adalah $\left(\mathrm{O}_{5}+\mathrm{O}_{6}+\mathrm{O}_{7}+\mathrm{O}_{8}\right)-\left(\mathrm{O}_{1}\right.$ $\left.+\mathrm{O}_{2}+\mathrm{O}_{3}+\mathrm{O}_{4}\right)$. Dalam penelitian, pengaruh perlakuan dianalisis dengan uji beda menggunakan statistik $t$-test. Jika ada perbedaan yang signifikan antara pre-test dan post-test maka perlakuan yang diberikan berpengaruh secara signifikan

\section{HASIL DAN PEMBAHASAN}

Pada penelitian ini dibagi menjadi 3 tahap :

1. Tahap I

Merancang Schematic Electronic Component Tester dengan software eagle dan merancang program menggunakan software WinAVR kemudian melakukan validasi terhadap rancangan tersebut.

Untuk menguji validitas schematic rangkaian, dilakukan simulasi menggunakan software elektronika (eagle). Setelah didapatkan hasil yang sesuai dengan teoritis maka dilanjutkan ke tahap selanjutnya yaitu membuat layout PCB dengan software $\mathrm{PCB}$ eagle serta melakukan proses pencetakan dan pengeboran PCB.

2. Tahap II

Pada tahap II dilakukan perakitan komponen. Setelah perancangan perangkat keras dan perangkat lunak alat Electronic Component Tester, langkah selanjutnya memasang kerangka box untuk memberikan tampilan fisik alat menjadi menarik dan rapi. Pemasangan box ini juga akan melindungi kompo nen rangkaian dari debu dan pengaruh lingkungan luar. Pada gambar 1. merupakan bagian keseluruhan dari sistem pada Electronic Component Tester yang berfungsi untuk mengidentifikasi beberapa komponen elektronika pasif dan aktif. Komponen yang akan diuji dipasang pada jamper yang terhubung pada terminal komponen tester kemudian tekan tombol (Rotary encoder) untuk melakukan uji komponen.

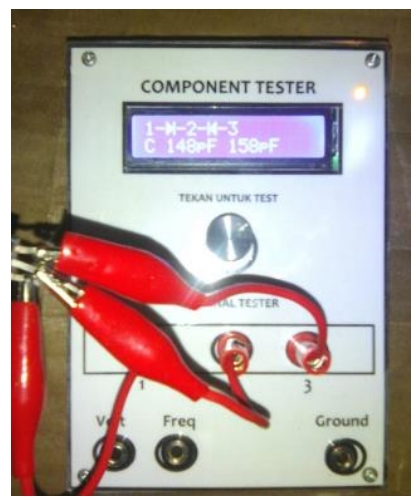

Gambar 1. Hasil pembuatan alat

Tabel 1. Bentuk display informasi pada Electronic Component Tester

\begin{tabular}{|l|c|l|}
\hline No & $\begin{array}{c}\text { Kondisi Display } \\
\text { Electronic } \\
\text { Component Tester }\end{array}$ & Keterangan \\
\hline 1 & & $\begin{array}{l}\text { Kondisi alat } \\
\text { mati }\end{array}$ \\
\hline 2 & $\begin{array}{l}\text { Sat, 6.80 Lenah } \\
\text { Henguji... }\end{array}$ & $\begin{array}{l}\text { Kondisi } \\
\text { Baterai }\end{array}$ \\
\hline 3 & $\begin{array}{l}\text { Tidak Ditenukan } \\
\text { atzu Part Rusak: }\end{array}$ & $\begin{array}{l}\text { Komponen } \\
\text { yang diuji } \\
\text { rusak atau } \\
\text { komponen } \\
\text { belum } \\
\text { dihubungkan } \\
\text { ke probe } \\
\text { terminal }\end{array}$ \\
\hline
\end{tabular}

Alat component tester mampu menguji beberapa komponen elektronika pasif dan 
aktif seperti resistor, kapasitor, induktor, transistor, dioda, FET, dan thyristor.

\section{Setelah}

dilakukan

pengujian beberapa komponen elektronika aktif dan pasif dengan menggunakan electronic component tester dan dibandingkan dengan menggunakan alat ukur multitester, LCR Tester dan datasheet persentase tingkat keberhasilan electronic Component Tester seperti pada tabel 2.

Tabel 2. Rata-Rata Tingkat Persentase Keberhasilan.

\begin{tabular}{|l|l|l|}
\hline No & $\begin{array}{l}\text { Jenis } \\
\text { Komponen }\end{array}$ & $\begin{array}{l}\text { Persentase } \\
\text { Keberhasilan } \\
(\%)\end{array}$ \\
\hline A. & Pasif & 90 \\
\hline 1 & Resistor & 100 \\
\hline 2 & Kapasitor & 80 \\
\hline 3 & Induktor & 100 \\
\hline B. & Aktif & 100 \\
\hline 4 & Dioda & 100 \\
\hline 5 & Transistor & 100 \\
\hline 6 & Mosfet & 95,71 \\
\hline 7 & Thyristor & \\
\hline \multicolumn{2}{|l|}{ Rata-Rata } \\
Persentase \\
Keberhasilan
\end{tabular}

Berdasarkan data pada tabel 2, rerata tingkat persentase keberhasilan electronic component tester dalam melakukan uji komponen elektronika pasif dan aktif sebesar $95,71 \%$. Berdasarkan data tersebut dapat disimpulkan bahwa electronic component tester memili-ki kemampuan dalam menguji komponen elektronika pasif dan aktif sehingga dapat memenuhi kompe-tensi dasar mengklasifikasikan komponen aktif dan pasif pada rangkaian listrik dan elektronika.

Tahap pengujian terhadap tingkat kelayakan penggunaan Electronic Component Tester sebagai media pembelajaran dilakukan dengan uji validasi yang meliputi validasi oleh guru dan ahli media.

Uji validasi ini berupa angket penilaian yang dinilai oleh guru sebagai ahli materi. Penilaian ditinjau berdasar-kan tiga aspek yaitu aspek desain fisik, teknis dan instruksional.

Perolehan rata-rata persen-tase tingkat kelayakan electronic component tester pada keseluruhan aspek sebagai media pembelajaran Kompetensi Dasar mengklasifikasikan komponen aktif dan pasif pada rangkaian listrik dan elektronika. yang diujikan kepada dua orang guru adalah sebesar $89,91 \%$. Berdasarkan data tingkat persentase kelayakan dari keseluruhan aspek tersebut dapat disimpulkan bahwa electronic component tester layak digunakan sebagai media pembelajaran di SMK pada kompetensi Dasar mengklasifikasikan komponen aktif dan pasif pada rangkaian listrik dan elektronika.

Perolehan rata-rata persentase tingkat kelayakan electronic compo-nent tester pada keseluruhan aspek sebagai 
media pembelajaran pada kompetensi Dasar mengklasifikasikan komponen aktif dan pasif pada rangkaian listrik dan elektronika yang diujikan kepada dua orang ahli media adalah sebesar 90,63\%. Berdasarkan data tingkat persentase kelayakan dari keseluruhan aspek tersebut dapat disimpulkan bahwa electronic component tester layak digunakan sebagai media pembelajaran.

\section{Tahap III}

Pada tahap ini diterapkan Electronic Component Tester sebagai media pembelajaran. Penelitian ini dilakukan di SMKN 1 Sumbar program keahlian Teknik Audio Video tahun ajaran 2017/2018 pada kompetensi dasar mengklasifikasi komponen pasif dan aktif pada rangkaian listrik dan elektronika. Sebelum mengadakan suatu penelitian diperlukan perlengkapan untuk mendapatkan hasil penelitian, pengambilan sampel dan uji perlengkapan instrumen penelitian. Sampel pada penelitian ini terdiri dari 2 kelas, yaitu kelas TAV A dengan jumlah siswa 14 orang dan kelas TAV B dengan jumlah siswa 14 orang. Dimana sebelum diberi perlakuan masing-masing kelas diberikan pre-test.

Sebelum tes diberikan, untuk menentukan apakah suatu instrumen layak dipakai sebagai alat pengumpul data dalam penelitian, terlebih dahulu dilakukan uji coba untuk mengetahui validitas, reliabilitas, dan indeks kesukaran terhadap instrumen. Instrumen yang digunakan dalam penelitian ini adalah tes objektif berupa pilihan ganda. Uji coba dilakukan pada mahasiswa teknik elektronika dengan jumlah 41 orang. Soal yang telah diuji digunakan sebagai soal yang akan dihitung dalam pengambilan nilai pre-test dan post-test. Jumlah soal uji coba adalah sebanyak 15 soal untuk pertemuan pertama, kedua, dan ketiga serta 10 soal untuk pertemuan keempat. Kemudian setelah di uji cobakan dan dilakukan uji validitas, reliabilitas, dan tingkat kesukaran, tersisa 15 soal untuk pertemuan pertama, 12 soal untuk pertemuan kedua, 12 soal untuk pertemuan ketiga dan 9 soal untuk pertemuan ke empat. Hasil yang diperoleh dalam penelitian ini adalah berupa hasil studi lapangan untuk memperoleh data teknis pre-test dan post-test di setiap pertemuan. Penelitian ini bertujuan untuk mengetahui pengaruh penerapan media Electronic Component Tester terhadap hasil belajar pada kompetensi dasar mengklasifikasi komponen pasif dan aktif pada rangkaian listrik dan elektronika siswa program keahlian Teknik Audio Video di SMK N 1 Sumbar.

a. Pelaksanaan Pembelajaran

Kegiatan penelitian ini dilaksanakan dari bulan Oktober - November 2017. Sebelum kegiatan penelitian dilaksanakan, peneliti menentukan kompetensi dasar yang sesuai dengan media pembelajaran yang akan diterapkan.

b. Analisis Induktif

1) Kelas TAV A

Setelah dilakukan perhitungan statistik maka diperoleh hasil Sebagai berikut : 
Tabel 3. Data hasil olahan statistik penerapan media pembelajaran pada kelas TAV A

\begin{tabular}{|c|c|c|c|c|c|c|}
\hline Kegiatan & $\mathbf{N}$ & $\begin{array}{l}\text { Rata- } \\
\text { rata }\end{array}$ & $\begin{array}{l}\text { Standart } \\
\text { Deviasi }\end{array}$ & $\begin{array}{l}\text { Nilai t } \\
\text { hitung }\end{array}$ & df & t-tabel \\
\hline pre-test 1 & 14 & 52,14 & 12,78 & \multirow{2}{*}{2,167} & \multirow{2}{*}{26} & \multirow{2}{*}{2,056} \\
\hline post-test-1 & 14 & 61,86 & 10,88 & & & \\
\hline pre-test 2 & 14 & 51,21 & 13,07 & \multirow{3}{*}{2,153} & \multirow{3}{*}{26} & \multirow{3}{*}{2,056} \\
\hline & & & & & & \\
\hline post-test 2 & 14 & 61,36 & 20,2 & & & \\
\hline pre-test 3 & 14 & 50,64 & 15,8 & \multirow{2}{*}{2,103} & \multirow[b]{2}{*}{26} & \multirow{2}{*}{2,056} \\
\hline post-test 3 & 14 & 64,86 & 21,05 & & & \\
\hline pre-test 4 & 14 & 48,38 & 15,1 & \multirow{3}{*}{2,132} & \multirow{3}{*}{26} & \multirow{3}{*}{2,056} \\
\hline & & & & & & \\
\hline post-test 4 & 14 & 59,62 & 12,94 & & & \\
\hline $\begin{array}{l}\text { Rata-rata } \\
\text { pre-test }\end{array}$ & 14 & 50,60 & 9,59 & \multirow{3}{*}{2,905} & \multirow{3}{*}{26} & \multirow{3}{*}{2,056} \\
\hline & & & & & & \\
\hline $\begin{array}{l}\text { Rata-rata } \\
\text { post-test }\end{array}$ & 14 & 61,90 & 10,93 & & & \\
\hline
\end{tabular}

Terlihat pada tabel 3 , dengan taraf signifikan $\alpha=0,05$. Jika dibandingkan ternyata $t_{\text {hitung }}>t_{\text {tabel }}$, sehingga terlihat bahwa nilai thitung lebih besar dari nilai tabel. Hasil belajar siswa setelah diberi perlakuan penggunaan media pembelajaran Electronic Component Tester (post-test) lebih baik daripada hasil belajar siswa sebelum diberi perlakuan menggunakan media pembelajaran (pre-test) terhadap hasil belajar kompetensi dasar menerapkan komponen aktif dan pasif pada rangkaian listrik dan elektronika pada jurusan Teknik Audio Video di SMKN 1 Sumatera Barat.

2) Kelas TAV B

setelah dilakukan perhitungan statistik maka diperoleh hasil Sebagai berikut :
Tabel 4. Data hasil olahan statistik penerapan media pembelajaran pada kelas TAV B

\begin{tabular}{|c|c|c|c|c|c|c|}
\hline Kegiatan & $\mathbf{N}$ & $\begin{array}{l}\text { Rata } \\
\text {-rata }\end{array}$ & $\begin{array}{l}\text { Standart } \\
\text { Deviasi }\end{array}$ & $\begin{array}{l}\text { Nilai t } \\
\text { hitung }\end{array}$ & df & t-tabel \\
\hline pre-test 1 & 14 & $\begin{array}{l}51,7 \\
9\end{array}$ & 11,62 & \multirow{2}{*}{2,228} & \multirow{2}{*}{26} & \multirow{2}{*}{2,056} \\
\hline post-test-1 & 14 & $\begin{array}{l}61,0 \\
7\end{array}$ & 10,38 & & & \\
\hline pre-test 2 & 14 & $\begin{array}{l}51,0 \\
7\end{array}$ & 11,81 & \multirow{2}{*}{2,603} & \multirow{2}{*}{26} & \multirow{2}{*}{2,056} \\
\hline post-test 2 & 14 & $\begin{array}{l}61,4 \\
3\end{array}$ & 9,07 & & & \\
\hline pre-test 3 & 14 & $\begin{array}{l}42,8 \\
6\end{array}$ & 14,31 & \multirow{2}{*}{2,17} & \multirow{2}{*}{26} & \multirow{2}{*}{2,056} \\
\hline post-test 3 & 14 & $\begin{array}{l}60,6 \\
4\end{array}$ & 11,48 & & & \\
\hline pre-test 4 & 14 & $\begin{array}{l}49,2 \\
1\end{array}$ & 13,92 & \multirow{2}{*}{2,988} & \multirow{2}{*}{26} & \multirow{2}{*}{2,056} \\
\hline post-test 4 & 14 & $\begin{array}{l}63,0 \\
0\end{array}$ & 10,36 & & & \\
\hline $\begin{array}{l}\text { Rata-rata } \\
\text { pre-test }\end{array}$ & 14 & $\begin{array}{l}48,6 \\
4\end{array}$ & 7,42 & \multirow{2}{*}{4,407} & \multirow{2}{*}{26} & \multirow{2}{*}{2,056} \\
\hline $\begin{array}{l}\text { Rata-rata } \\
\text { post-test }\end{array}$ & 14 & $\begin{array}{l}61,7 \\
1\end{array}$ & 8,25 & & & \\
\hline
\end{tabular}

Terlihat pada tabel 4, dengan taraf signifikan $\alpha=0,05$. Jika dibandingkan ternyata $t_{\text {hitung }}>t_{\text {tabel, }}$ sehingga terlihat bahwa nilai thitung lebih besar dari nilai $t_{\text {tabel. }}$ Hasil belajar siswa setelah diberi perlakuan penggunaan media pembelajaran Electronic Component Tester (post-test) lebih baik daripada hasil belajar siswa sebelum diberi perlakuan menggunakan media pembelajaran (pre-test) terhadap hasil belajar kompetensi dasar menerapkan komponen aktif dan pasif pada rangkaian listrik dan elektronika pada jurusan Teknik Audio Video di SMKN 1 Sumatera Barat. 
c. Besarnya pengaruh

Untuk mengetahui besarnya pengaruh hasil belajar siswa sebelum diberi perlakuan (hasil pre-test) dengan setelah diberi perlakuan ( hasil post-test) dapat dilakukan perhitungan dengan rumus :
Berdasarkan pembahasan diatas, penerapan pada dua kelas yang berbeda terlihat bahwa media pembelajaran electronic component tester dapat meningkatkan hasil belajar siswa.

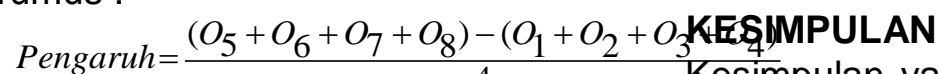

$$
\begin{aligned}
& \text { Dimana : } \\
& \mathrm{O}_{1}, \mathrm{O}_{2}, \mathrm{O}_{3}, \mathrm{O}_{4}=\text { rata-rata nilai } \\
& \text { pre-test } \\
& \mathrm{O}_{5}, \mathrm{O}_{6}, \mathrm{O}_{7}, \mathrm{O}_{8}=\text { rata-rata nilai } \\
& \text { post-test }
\end{aligned}
$$

Kesimpulan yang dapat diambil dari penelitian ini adalah sebagai berikut:

1. Dihasilkan media pembelajaran interaktif Electronic Component Tester sebagai media yang tepat untuk komptensi dasar mengklasifikasi komponen aktif dan pasif pada rangkaian listrik dan elektronika pada program keahlian teknik audio video SMK

1) Persentase pengaruh penggunaan media pembelajaran Electronic Component Tester Kelas TAV A

Pengaruh $=\frac{\left(\mathrm{O}_{5}+\mathrm{O}_{6}+\mathrm{O}_{7}+\mathrm{O}_{8}\right)-\left(\mathrm{O}_{1}+\mathrm{O}_{2}+\mathrm{O}_{3}+\mathrm{O}_{4}\right)}{4}$

2. Terdapat peningkatan hasil belajar sebesar 11,31 untuk Pengarul $=\frac{(61,86+61,36+64,86+59,52)-(52,14+51,21+50,64+48, \text { kelas TAV A dan 12,80 untuk }}{4}$ kelas TAV B setelah diterapkan Pengaruh $=\frac{247,60-202,37}{4}$ media pembelajaran Electronic Component Tester

Pengaruh $=11,31$

Dari hasil perhitungan didapatkan peningkatan hasil belajar siswa sebesar 11,31 setelah diberi perlakuan dengan menggunakan media pembelajaran Electronic Component Tester.

2) Persentase pengaruh penggunaan media pembelajaran Electronic Component Tester Kelas TAV B

Pengaruh $=\frac{\left(\mathrm{O}_{5}+\mathrm{O}_{6}+\mathrm{O}_{7}+\mathrm{O}_{8}\right)-\left(\mathrm{O}_{1}+\mathrm{O}_{2}+\mathrm{O}_{3}+\mathrm{O}_{4}\right)}{4}$

\section{DAFTAR PUSTAKA}

[1] Agfianto Eko Putra. 2011.Tutorial Pemograman Mikrokontroller AVR dengan CAVR dan WINAVR GCC.Pdf.Yogyakarta:

[2] Antoious Rahmat C.2010.Algoritma dan Pemograman dengan Bahasa C (Konsep Teori dan Implementasi). Yogyakarta : Penerbit Andi.

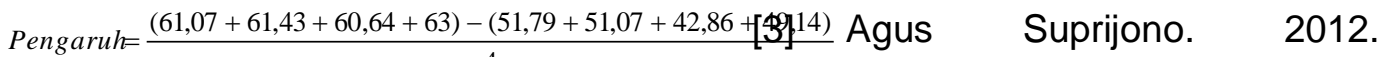
Pengaruh $=\frac{246,14-194,93}{4}$

Pengaruh $=12,80$

Dari hasil perhitungan didapatkan peningkatan hasil belajar siswa sebesar 12,80 setelah diberi perlakuan dengan menggunakan media pembelajaran Electronic Component Tester. Cooperative Learning Teori \& Aplikasi PAIKEM. Yogyakarta: Pustaka Pelajar.

[4] Azhar Arsyad. 2013. Media Pembelajaran.Jakarta:Rajawali Pers. 
[5] Arief S Sadiman dkk. 2012. Media Pendidikan Pengertian, Pengembangan, dan Pemanfaatannya. Jakarta : PT Raja Grafindo Persada.

[6] Cecep \& Bambang.2011.Media Pembelajaran Manual dan Digital.Bogor:Ghalia Indonesia.

[7] Ekayana, G., Suharsono, N., dan Tengeh, M,.2013. Pengembangan Perangkat Pembelajaran Mikrokontroler Berbasis Advance Virtual RISC (AVR) dalam Mata Pelajaran Teknik Mikrokontroller. Jakarta: Universitas Pendidikan Ganesha. E-Journal PPs. Vol 3.

[8] Fenrich,Peter.2005.Creating Instructional Multimedia
Solutions Practical Guidelines for The real World.California:Informing Science Press.

[9] Marvel, D. Ronald. 2014. programming With AVR Microcontroller.New York: Research Design Lab

[10] Nana Sudjana. (2011). Penilaian Hasil Proses Belajar Mengajar. Bandung: PT. Remaja Rosdakarya.

[11] Pasif Berbasis Microprosessor pada Mata Diklat Teknik Listrik di SMK Negeri 3 Surabaya. (Jurnal Pendidikan Teknik Elektro, Vol 3, No 3)

[12] Sugiyono. (2017). Metode Penelitian Kuantitatif, Kualitatif, dan R\&D. Bandung:Alfabeta 